\title{
SYNTHESIS AND IN VITRO ACTIVITY OF A NEW \\ CARBAPENEM, RS-533
}

\author{
Tetsuo Miyadera, Yukio Sugimura, Toshiniko Hashimoto, \\ Teruo Tanaka, Kimio Iino, Tomoyuki Shibata \\ and Shinichi Sugawara*
}

Chemical Research Laboratories and Research Institute*, Sankyo Co., Ltd., 1-2-58 Hiromachi, Shinagawa-ku, Tokyo 140, Japan

(Received for publication April 25, 1983)

The synthesis and in vitro antimicrobial activity of a new synthetic carbapenem, $(5 R, 6 S)-6-$ [(R)-1-hydroxyethyl]-2-[( $S)$-1-acetimidoylpyrrolidin-3-ylthio]-1-carbapen-2-em-3-carboxylic acid (RS-533), are described. The MIC values of related penems and carbapenems are also given for comparison with those of the new carbapenem.

The discovery of the potent broad-spectrum antibiotic thienamycin (THM) ${ }^{1 \sim 4)}$ has arisen chemical and microbiological interest in carbapenems and structurally related penems. Extensive molecular modifications of THM and penems have been made in pursuit of greater stability and potency and, as a result, clinically useful $\beta$-lactams, $N$-formimidoylthienamycin (MK0787) ${ }^{5 \sim 7)}$ and an oral penem (Sch $29482)^{8)}$ have been obtained. Prior to the present work on carbapenems, we were concerned with the synthesis $^{\theta, 10)}$ and bioassay of new penems, during which we discovered 6-(1-hydroxyethyl)-2-(pyrrolidin3-ylthio)penem-3-carboxylic acids $(\mathbf{R}-\mathbf{1} \text { and } \mathbf{S}-\mathbf{1})^{11,12}$ ) which were found to have potent in vitro activity comparable to THM. This finding led us to synthesize carbapenem congeners in the expectation that the carbapenems would display greater activity than either the penems or THM. As a result of extensive syntheses ranging from penems to carbapenems, we ultimately obtained a new carbapenem, RS533 ; one of the most promising antibiotics in view of the potent in vitro and in vivo activity ${ }^{13}$ ) against a wide range of bacteria.

\section{Chart 1.}
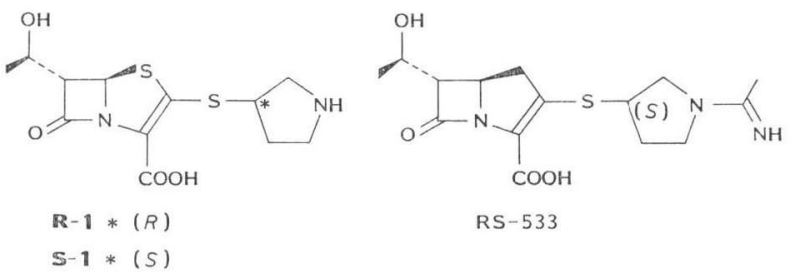

Synthesis

In preparing the desired carbapenem compound, we utilized the 2-oxocarbapenam (9b), first synthesized by the Merck group, ${ }^{14)}$ as the most reliable intermediate for carbapenem synthesis. Although $9 \mathrm{a}$ and $9 \mathrm{~b}$ have been synthesized by way of the $\beta$-keto esters ( $4 \mathrm{a}$ and $4 \mathrm{~b}$ ) by several routes, ${ }^{15 \sim 18}$ ) we prepared $\mathbf{4 a}$ and $\mathbf{4 b}$ starting from the acetoxyazetidinone (2) and the 3-pyrrolidinocrotonic acid esters as shown in Chart 2. 
Chart 2.

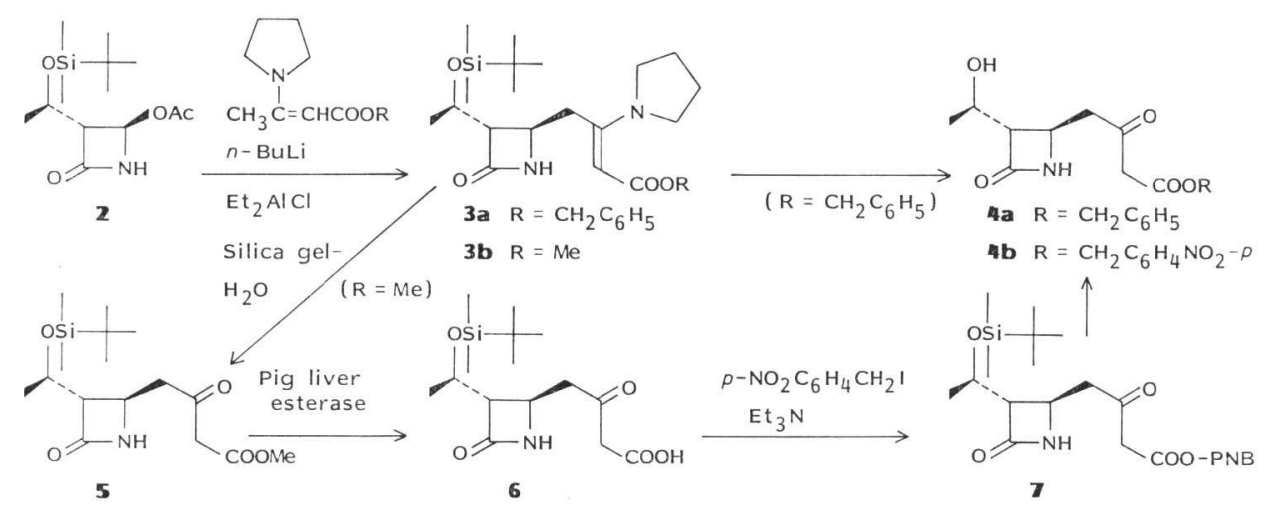

In the first attempt methyl 3-pyrrolidinocrotonate was, after lithiation with $n$-butyllithium, ${ }^{19)}$ allowed to react with $\mathbf{2}$ to furnish $\mathbf{5}$ in very poor yield. The $\beta$-keto ester (5) was, however, produced in reasonable yield when diethylaluminum chloride was added to the lithiated enamino ester prior to reaction with 2. In this process, the initially formed enamino ester (3b) was treated with silica gel containing a small amount of water to give the $\beta$-keto ester (5). The enamino ester (3a) similarly prepared was treated with aqueous $\mathrm{HCl}-\mathrm{MeOH}$ followed by hydrolysis using silica gel $-\mathrm{H}_{2} \mathrm{O}$ to give $4 \mathrm{a}$ in $33 \%$ yield from 2, while $p$-nitrobenzyl 3-pyrrolidinocrotonate failed to yield the corresponding $\beta$-keto ester ( $\mathbf{4 b}$ ). The $\beta$-keto ester (7) could be obtained by the hydrolysis of the $\beta$-keto methyl ester (5) with pig liver esterase to the $\beta$-keto acid (6) followed by esterification with $p$-nitrobenzyl iodide. The enzymatic hydrolysis has advantage over the acid or alkaline hydrolysis of $\beta$-keto esters to $\beta$-keto carboxylic acids which accompanies decarboxylation. Removal of the tert-butyldimethylsilyl group of 7 was performed by treatment with aqueous $\mathrm{HCl}$ in methanol. The $\beta$-keto esters ( $4 \mathrm{a}$ and $\mathbf{4 b}$ ) were converted into $9 \mathrm{a}$ and $\mathbf{9 b}$, respectively, via diazo compounds ( $\mathbf{8} \mathbf{a}$ and $\mathbf{8 b}$ ) according to the established method. ${ }^{14)}$ The 2-oxocarbapenams (9a and 9b) were treated with diphenylphosphoryl chloride in the presence of diisopropylethylamine ${ }^{14)}$ and then with $(S)$-1-p-nitrobenzyloxycarbonyl-3-mercaptopyrrolidine* to furnish the carbapenem derivatives (10a and $10 \mathrm{~b}$ ). Deprotection of the $p$-nitrobenzyl and $p$-nitrobenzyloxycarbonyl groups of $10 \mathrm{~b}$ was performed by hydrogenolysis over $10 \%$ Pd-C yielding 11 in good yield, while similar treatment of 10a gave 11 in poor yield. The pyrrolidinylthiocarbapenem (11) was crystallized from water to give the semihydrate of $\mathbf{1 1}$ as colorless fine prisms. Treatment of $\mathbf{1 1}$ with ethyl acetimidate afforded RS-533. The two carbapenems, 11 and RS-533, may be represented as zwitter ions. The NMR spectrum of RS-533 indicates that it exists in water as two interconvertible rotamers (approximately $1: 1$ ) possibly responsible for a double bond character of the acetimidoylpyrrolidinyl linkage. Details will be given in the near future. The $R$-epimer of RS-533 was similarly prepared starting from $9 \mathbf{b}$ and $(R)-1-p$-nitrobenzyloxycarbonyl-3mercaptopyrrolidine. The isomeric carbapenem will be described elsewhere, along with the $N$-formimidoyl derivative of $\mathbf{1 1}$ and other alicyclic amine derivatives. Alternative synthesis of carbapenems is now in progress.

* (S)-1-p-Nitrobenzyloxycarbonyl-3-mercaptopyrrolidine was prepared in the following four steps starting from (R)-3-hydroxypyrrolidine: 1) $p$ - $\mathrm{NO}_{2} \mathrm{C}_{8} \mathrm{H}_{4} \mathrm{CH}_{2} \mathrm{OCOCl}, \mathrm{Et}{ }_{3} \mathrm{~N} /$ cyclohexanol, $0^{\circ} \mathrm{C}$; 2) $\mathrm{MeSO}_{2} \mathrm{Cl}, \mathrm{Et}_{3} \mathrm{~N} / \mathrm{CH}_{2} \mathrm{Cl}_{2}$, $0^{\circ} \mathrm{C}$; 3) $\mathrm{AcSNa} / \mathrm{DMF}, 60^{\circ} \mathrm{C}$; 4) $\mathrm{MeONa} / \mathrm{MeOH}, 0^{\circ} \mathrm{C}$. (R)-3-Hydroxypyrrolidine was prepared from trans-4hydroxy-L-proline according to the known method. ${ }^{20)}$ 
Chart 3 .

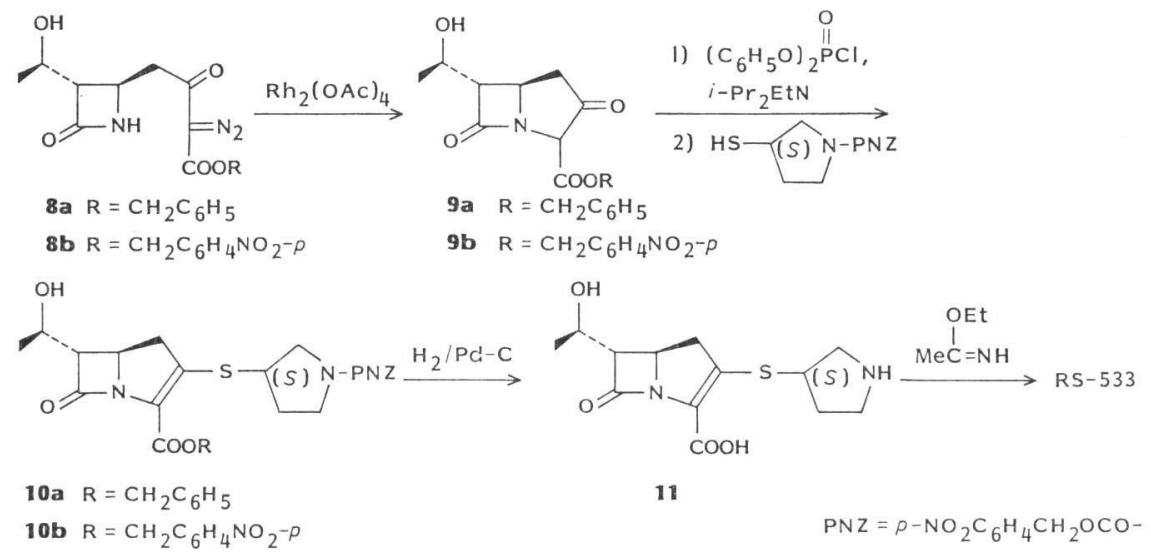

Table 1. Antimicrobial activities of RS-533, 11, S-1, R-1, and THM.

\begin{tabular}{|c|c|c|c|c|c|}
\hline \multirow{2}{*}{ Organism } & \multicolumn{5}{|c|}{$\mathrm{MIC}(\mu \mathrm{g} / \mathrm{ml})$} \\
\hline & RS-533 & 11 & S-1 & R-1 & THM \\
\hline Bacillus subtilis PCI-219 & $\leqq 0.01$ & $\leqq 0.01$ & $\leqq 0.01$ & $\leqq 0.01$ & $\leqq 0.01$ \\
\hline Staphylococcus aureus 209P & $\leqq 0.01$ & $\leqq 0.01$ & $\leqq 0.01$ & $\leqq 0.01$ & $\leqq 0.01$ \\
\hline Staphylococcus aureus 56* & $\leqq 0.01$ & $\leqq 0.01$ & $\leqq 0.01$ & $\leqq 0.01$ & $\leqq 0.01$ \\
\hline Escherichia coli NIHJ & 0.05 & 0.02 & 0.1 & 0.05 & 0.1 \\
\hline Escherichia coli $609 * *$ & 0.05 & 0.02 & 0.1 & 0.05 & 0.1 \\
\hline Salmonella enteritidis Gaertner & 0.05 & 0.05 & 0.2 & 0.1 & 0.2 \\
\hline Shigella flexneri 2 a Komagome & 0.02 & $\leqq 0.01$ & 0.1 & 0.05 & 0.1 \\
\hline Klebsiella pneumoniae 806 & 0.05 & 0.02 & 0.2 & 0.1 & 0.1 \\
\hline Enterobacter cloacae 963 & 0.4 & 0.4 & 3.1 & 3.1 & \\
\hline Serratia marcescens 1850 & 0.1 & 0.05 & 0.4 & 0.2 & \\
\hline Proteus vulgaris 1420 & 1.5 & 3.1 & 6.2 & 3.1 & 3.1 \\
\hline Pseudomonas aeruginosa 1001 & 6.2 & 1.5 & 6.2 & 6.2 & 6.2 \\
\hline
\end{tabular}

* Penicillinase producer.

** Cephalosporinase producer.

Nutrient agar: Inocula were diluted 100-fold after overnight culture. Final inoculum size was oneloopful of $10^{7} \mathrm{cfu} / \mathrm{ml}$.

\section{Antimicrobial Activity}

The in vitro antimicrobial activities of RS-533 and $\mathbf{1 1}$ were tested by the serial agar dilution method. The minimal inhibitory concentrations (MIC) against a variety of Gram-positive and Gram-negative bacteria are listed in Table 1 and compared with those of THM, R-1 and S-1. The carbapenem $\mathbf{1 1}$ is $4 \sim 5$ times more active than THM against Escherichia coli, Klebsiella pneumoniae, Pseudomonas aeruginosa, etc. Although RS-533 is slightly less active than $\mathbf{1 1}$ as far as the in vitro activity concerned, the former proved to be better in mice infected with a variety of bacteria.

\section{Experimental}

IR spectra were recorded on a Jasco A-2 spectrometer and UV spectra were obtained on a Cary 14 CM-50 (Serial 1258) spectrometer. Nuclear magnetic resonance spectra were recorded on a Jeol 
JNM GX-400 or a Varian EM 360L spectrometer. Chemical shifts are reported in parts per million (o) using, unless otherwise specified, tetramethylsilane (TMS) as an internal standard. Rotations were determined on a Perkin-Elmer 241 polarimeter.

Benzyl 4-[(3S,4R)-3-[(R)-1-Hydroxyethyl]-2-oxoazetidin-4-yl]-3-oxobutyrate (4a)

A solution of benzyl 3-pyrrolidinocrotonate $(5.81 \mathrm{~g}, 20 \mathrm{mmol})$ in THF $(70 \mathrm{ml})$ was treated with a solution of $n$-BuLi $(20 \mathrm{mmol})$ of hexane $(12.3 \mathrm{ml}, 1.63 \mathrm{mmol} / \mathrm{ml})$ according to the procedure given in ref 19. To the resulting solution was added a solution of $\mathrm{Et}_{2} \mathrm{AlCl}(20 \mathrm{mmol})$ in hexane $(23.0 \mathrm{ml}, 0.871$ $\mathrm{mmol} / \mathrm{ml})$ at $-60^{\circ} \mathrm{C}$ with stirring. The mixture was stirred for 45 minutes at the same temperature and a solution of $2(1.15 \mathrm{~g}, 4 \mathrm{mmol})$ in THF $(10 \mathrm{ml})$ was added dropwise. After being stirred at $-60^{\circ} \mathrm{C}$ for 0.5 hour and at $0^{\circ} \mathrm{C}$ for 45 minutes, the mixture was poured into ice-water and extracted with EtOAc. After removal of the insoluble material by filtration, the extract was washed with water, dried over $\mathrm{MgSO}_{4}$ and evaporated in vacuo to leave an oily residue. The oil was dissolved in a mixture of conc. $\mathrm{HCl}(10 \mathrm{ml})$ and $\mathrm{MeOH}(50 \mathrm{ml})$ and the solution was stirred at $0^{\circ} \mathrm{C}$ for 1 hour. The mixture was neutralized with $5 \%$ aq. $\mathrm{NaHCO}_{3}$ and extracted with EtOAc. The extract was washed with aq. $\mathrm{NaCl}$ and dried over $\mathrm{MgSO}_{4}$, and the residue obtained by removal of the solvent was treated with silica gel $(30 \mathrm{~g})$ in benzene $(50 \mathrm{ml})-\mathrm{H}_{2} \mathrm{O}(4.5 \mathrm{ml})$ at room temperature for 1 hour. The mixture was loaded on silica gel and chromatographed eluting with EtOAc - $\mathrm{MeOH}(30: 1)$ to give $4 \mathrm{a}$ (402 $\mathrm{mg}, 33 \%$ yield) as an oil. $\operatorname{NMR}\left(\mathrm{CDCl}_{3}\right) \delta 1.22(3 \mathrm{H}, \mathrm{d}, J=6.0 \mathrm{~Hz}), 2.6 \sim 3.0(3 \mathrm{H}, \mathrm{m}), 3.50(2 \mathrm{H}, \mathrm{s}), 3.3 \sim 4.3(3 \mathrm{H}, \mathrm{m}), 5.11(2 \mathrm{H}$, s), $6.77\left(1 \mathrm{H}\right.$, br.s), $7.31(5 \mathrm{H}, \mathrm{s})$. IR $\left(\mathrm{CHCl}_{8}\right) 3430,1755,1710 \mathrm{~cm}^{-1}$.

Methyl 4-[3S,4R)-3-[(R)-1-tert-Butyldimethylsilyloxyethyl]-2-oxoazetidin-4-yl]-3-oxobutyrate (5)

Methyl 3-pyrrolidinocrotonate $\left.{ }^{19}\right)(10.2 \mathrm{~g}, 60.3 \mathrm{mmol})$ was treated successively with $n$-BuLi $(37.0 \mathrm{ml}$, $60.3 \mathrm{mmol}), \mathrm{Et}_{2} \mathrm{AlCl}(69.3 \mathrm{ml}, 0.870 \mathrm{mmol} / \mathrm{ml})$ and $2(3.47 \mathrm{~g}, 12.1 \mathrm{mmol})$ as described for $4 \mathrm{a}$. Without $\mathrm{HCl}$ treatment the crude product was subjected to hydrolysis with silica gel $-\mathrm{H}_{2} \mathrm{O}$ and then chromatographed on silica gel with cyclohexane - EtOAc $(1: 4)$ to give $5(1.25 \mathrm{~g}, 30 \%$ yield) as an oil. NMR $\left(\mathrm{CDCl}_{3}\right) \delta 0.08(6 \mathrm{H}, \mathrm{s}), 0.88(9 \mathrm{H}, \mathrm{s}), 1.22(3 \mathrm{H}, \mathrm{d}, J=6.5 \mathrm{~Hz}), 2.4 \sim 3.1(3 \mathrm{H}, \mathrm{m}), 3.48(2 \mathrm{H}, \mathrm{s}), 3.75(3 \mathrm{H}$, s), $3.8 \sim 4.4(2 \mathrm{H}, \mathrm{m}), 6.15(1 \mathrm{H}, \mathrm{br} . \mathrm{s})$. IR $\left(\mathrm{CHCl}_{3}\right) 3420,1755,1720 \mathrm{~cm}^{-1}$.

$p$-Nitrobenzyl 4-[(3S,4R)-3-[(R)-1-tert-Butyldimethylsilyloxyethyl]-2-oxoazetidin-4-yl]-3-oxobutyrate (7)

A mixture of $5(2.0 \mathrm{~g}, 5.8 \mathrm{mmol})$ and pig liver esterase (Sigma, $100 \mathrm{mg}$ ) in $0.2 \mathrm{M}$ phosphate buffer $\left(\mathrm{pH} 8.0,150 \mathrm{ml}\right.$ ) was vigorously stirred for 75 minutes at $36^{\circ} \mathrm{C}$ until it turned to be a homogeneous so!ution. The reaction mixture was diluted with EtOAc and the insoluble material was removed by filtration. The aqueous layer was washed with EtOAc, adjusted to $\mathrm{pH} 2.5$ with aq. $10 \% \mathrm{KHSO}_{4}$ and extracted with EtOAc. The extract was washed with aq. $\mathrm{NaCl}$, dried over $\mathrm{MgSO}_{4}$ and evaporated in vacuo to give $\mathbf{6}(1.33 \mathrm{~g})$ as a powder. The crude $\mathbf{6}(1.33 \mathrm{~g})$ was esterified by treating with a solution of $p$ nitrobenzyl iodide $(2.0 \mathrm{~g}, 5.51 \mathrm{mmol})$ and $\mathrm{Et}_{3} \mathrm{~N}(771 \mu 1,5.51 \mathrm{mmol})$ in DMF $(30 \mathrm{ml})$ at $0^{\circ} \mathrm{C}$ for 2 hours. The mixture was quenched with $\mathrm{AcOH}$, poured into ice-water and extracted with EtOAc. The extract was washed successively with aq. $5 \% \mathrm{HCl}$, aq. $\mathrm{NaHCO}_{3}$ and aq. $\mathrm{NaCl}$, and dried over $\mathrm{MgSO}_{4}$. The solvent was evaporated in vacuo and the residue was chromatographed on silica gel eluting with cyclohexane - EtOAc $(1: 2)$ to give $7(0.9 \mathrm{~g})$ as an oil. Spectral data of 7 were in accord with the literature ${ }^{14)}$ in all respects.

$p$-Nitrobenzyl $\quad(5 R, 6 S)-6-[(R)-1$-Hydroxyethyl]-2-[(S)-1-p-nitrobenzyloxycarbonylpyrrolidin-3-ylthio]-1-carbapen-2-em-3-carboxylate (10b)

Diphenylphosphoryl chloride $(1.76 \mathrm{ml}, 8.62 \mathrm{mmol})$ and iso- $\operatorname{Pr}_{2} \mathrm{EtN}(1.50 \mathrm{ml}, 8.62 \mathrm{mmol})$ were added to an ice-cooled solution of $9 \mathrm{~b}(2.50 \mathrm{~g}, 7.18 \mathrm{mmol})$ in anhydrous $\mathrm{CH}_{3} \mathrm{CN}(100 \mathrm{ml})$ and the mixture was stirred for 0.5 hour. Then iso- $\operatorname{Pr}_{2} \operatorname{EtN}(1.50 \mathrm{ml}, 8.62 \mathrm{mmol})$ and a solution of 3- $(S)$-mercapto-1-p-nitrobenzyloxycarbonylpyrrolidine $(2.43 \mathrm{~g}, 8.62 \mathrm{mmol})$ in $\mathrm{CH}_{3} \mathrm{CN}(7 \mathrm{ml})$ were added and the mixture was stirred at $0^{\circ} \mathrm{C}$ for 1 hour. The reaction mixture was diluted with EtOAc, washed successively with $\mathrm{H}_{2} \mathrm{O}$, aq. $5 \% \mathrm{NaHCO}_{3}$ and aq. $\mathrm{NaCl}$, and dried over $\mathrm{MgSO}_{4}$. The solvent was evaporated in vacuo to leave a residue which was treated with a small amount of EtOAc to give $10 \mathbf{b}(2.79 \mathrm{~g})$ as a powder. The filtrate was chromatographed on silica gel with EtOAc to give additional amount of $10 \mathrm{~b}(1.00 \mathrm{~g})$ 
as a powder. Yield 86\%. NMR $\left(\mathrm{CDCl}_{3}\right) \delta 1.34(3 \mathrm{H}, \mathrm{d}, J=6.0 \mathrm{~Hz}), 1.9 \sim 3.0(3 \mathrm{H}, \mathrm{m}), 3.1 \sim 4.5(10 \mathrm{H}$, $\mathrm{m}), 5.24(2 \mathrm{H}, \mathrm{s}), 5.22,5.53(2 \mathrm{H}, \mathrm{AB}-\mathrm{q}, J=14.0 \mathrm{~Hz}), 7.52,8.21\left(4 \mathrm{H}, \mathrm{A}_{2} \mathrm{~B}_{2}, J=9.0 \mathrm{~Hz}\right), 7.66,8.21(4 \mathrm{H}$, $\left.\mathrm{A}_{2} \mathrm{~B}_{2}, J=9.0 \mathrm{~Hz}\right) . \quad$ IR $(\mathrm{KBr}) 3560,1780,1705,1350 \mathrm{~cm}^{-1}$.

Benzyl (5R,6S)-6-[(R)-1-Hydroxyethyl]-2-[(S)-1-p-nitrobenzyloxycarbonylpyrrolidin-3-ylthio]-1carbapen-2-em-3-carboxylate (10a)

The benzyl ester 10a (303 mg) was obtained from $9 \mathbf{a}(280 \mathrm{mg}, 0.92 \mathrm{mmol})$ as described for $\mathbf{1 0 b}$. NMR $\left(\mathrm{DMF}-d_{7}\right) \delta 1.23(3 \mathrm{H}, \mathrm{d}, J=6.0 \mathrm{~Hz}), 1.7 \sim 2.7(2 \mathrm{H}, \mathrm{m}), 3.1 \sim 4.5(10 \mathrm{H}, \mathrm{m}), 5.06,5.33(2 \mathrm{H}, \mathrm{AB}-\mathrm{q}$, $J=16.5 \mathrm{~Hz}), 5.31(2 \mathrm{H}, \mathrm{s}), 7.2 \sim 7.7(5 \mathrm{H}, \mathrm{m}), 7.73,8.26\left(4 \mathrm{H}, \mathrm{A}_{2} \mathrm{~B}_{2}, J=8.5 \mathrm{~Hz}\right) . \quad$ IR (Nujol) 3400,1770 , $1708,1695,1350 \mathrm{~cm}^{-1}$.

(5R,6S)-6-[(R)-1-Hydroxyethyl]-2-[(S)-pyrrolidin-3-ylthio]-1-carbapen-2-em-3-carboxylic Acid (11)

a) A mixture of $10 \mathrm{~b}(5.00 \mathrm{~g}, 8.17 \mathrm{mmol})$ in a solution of THF $(100 \mathrm{ml})$ and $0.1 \mathrm{M}$ phosphate buffer $(\mathrm{pH} 7.0,100 \mathrm{ml})$ was shaken with $10 \% \mathrm{Pd}-\mathrm{C}(4.0 \mathrm{~g})$ for 1.5 hours under a $\mathrm{H}_{2}$ atmosphere. After removal of the catalyst by filtration through celite, the filtrate was concentrated in vacuo and filtered. The filtrate was washed with EtOAc, concentrated in vacuo to a half volume and chromatographed on a column of Diaion HP-20AG (Mitsubishi Chemical Industries, Ltd.). Fractions eluted with 5\% aq. acetone were lyophilized to give $\mathbf{1 1}\left(1.8 \mathrm{~g}, 74 \%\right.$ yield) as a powder which was crystallized from $\mathrm{H}_{2} \mathrm{O}$ to give fine prisms, $\mathrm{mp}>270^{\circ} \mathrm{C}$ (dec.). $[\alpha]_{\mathrm{D}}^{25}+73^{\circ}\left(c 0.31, \mathrm{H}_{2} \mathrm{O}\right) . \quad \mathrm{NMR}\left(400 \mathrm{MHz}, \mathrm{D}_{2} \mathrm{O} / \mathrm{TMS}_{\mathrm{ext}}\right) \delta 1.09(3 \mathrm{H}, \mathrm{d}, J=6.4 \mathrm{~Hz}$, $\left.\mathrm{CH}_{3} \mathrm{CH}\right), 1.86(1 \mathrm{H}$, dddd, $J=14, \sim 7, \sim 7, \sim 7 \mathrm{~Hz}$, pyrrolidine $\mathrm{H}-4), 2.31$ (1H, dddd, $J=14, \sim 7, \sim 7, \sim 7$ $\mathrm{Hz}$, pyrrolidine H-4), 3.01, $3.03\left(2 \mathrm{H}, \mathrm{qd}, J_{\mathrm{g} \text { em }}=17.5 \mathrm{~Hz}, J_{\mathrm{vic}}=9.8,8.8 \mathrm{~Hz}\right.$, respectively, $\left.2 \times \mathrm{H}-1\right), 3.16$ (1H, dd, $J=12.4,4.4 \mathrm{~Hz}$, pyrrolidine H-2), $3.20 \sim 3.25(2 \mathrm{H}, \mathrm{m}, \mathrm{H}-6$, pyrrolidine H-5), $3.31 \sim 3.37$ (1H, $\mathrm{m}$, pyrrolidine H-5), 3.51 ( $1 \mathrm{H}$, dd, $J=12.4,6.6 \mathrm{~Hz}$, pyrrolidine $\mathrm{H}-2), 3.80 \sim 3.85(1 \mathrm{H}, \mathrm{m}, \mathrm{SCH}), 4.00$ $\sim 4.07$ (2H, m, H-5, H-8). IR (KBr) 3400, 2800 2000, 1765, $1590 \mathrm{~cm}^{-1}$. UV $\lambda_{\max }^{\mathrm{H}_{2} \mathrm{O}} \mathrm{nm}(\varepsilon) 297(8,330)$.

Anal. Calcd. for $\mathrm{C}_{13} \mathrm{H}_{18} \mathrm{~N}_{2} \mathrm{O}_{4} \mathrm{~S} \cdot \frac{1}{2} \mathrm{H}_{2} \mathrm{O}$ : Found:

C 50.79, H 6.23, N 9.11, S 10.43 . C 51.12, H 6.23, N 9.20, S 10.46 .

b) The benzyl ester (10a) was treated with $\mathrm{H}_{2} / 10 \% \mathrm{Pd}-\mathrm{C}$ and worked up as described above to give 11 in yield of $9 \%$.

(5R,6S)-6-[(R)-1-Hydroxyethyl]-2 -[(S)-1-acetimidoylpyrrolidin-3-ylthio]-1 -carbapen-2 -em-3 -carboxylic Acid (RS-533)

A solution of $\mathbf{1 1}(3.3 \mathrm{~g}, 11.1 \mathrm{mmol})$ in $0.1 \mathrm{M}$ phosphate buffer $(\mathrm{pH} 7.0,350 \mathrm{ml})$ was adjusted to $\mathrm{pH}$ 8.5 with $1 \mathrm{~N} \mathrm{NaOH}$ at $0^{\circ} \mathrm{C}$ and ethyl acetimidate hydrochloride $(6.88 \mathrm{~g}, 55.5 \mathrm{mmol})$ was added in portions while adjusting to $\mathrm{pH}$ 8.5. After stirring for 10 minutes at $\mathrm{pH} 8.5$ the reaction mixture was neutralized with aq. $5 \% \mathrm{HCl}$ and passed through Diaion HP-20AG. Fractions eluted with aq. $5 \%$ acetone were lyophilized to give RS-533 (3.17 g, 84\% yield) as a powder. NMR (400 MHz, D 2 O/TMS $\left.\mathrm{Txt}_{\text {e }}\right) \delta 1.09(3 \mathrm{H}$, d, $\left.J=6.3 \mathrm{~Hz}, \mathrm{CH}_{3} \mathrm{CH}\right) .1 .87 \sim 1.99(1 \mathrm{H}, \mathrm{m}$, pyrrolidine $\mathrm{H}-4), 2.06,2.08\left(1.5 \mathrm{H}\right.$ each, s, $\left.\mathrm{CH}_{3} \mathrm{C}=\mathrm{N}\right), 2.10 \sim$ $2.35(1 \mathrm{H}, \mathrm{m}$, pyrrolidine $\mathrm{H}-4), 3.01,3.05\left(0.5 \mathrm{H}\right.$ each, qd, $J_{\mathrm{gem}}=17.6 \mathrm{~Hz}, J_{\mathrm{vic}}=8.8,9.8 \mathrm{~Hz}$, respectively, $\mathrm{H}-1), 3.00,3.06\left(0.5 \mathrm{H}\right.$ each, qd, $J_{\text {gem }}=17.6 \mathrm{~Hz}, J_{\text {vic }}=8.8,9.8 \mathrm{~Hz}$, respectively, H-1), $3.23(1 \mathrm{H}, \mathrm{dd}, J=$ 5.9, $2.5 \mathrm{~Hz}, \mathrm{H}-6), 3.24 \sim 3.89$ (4H, m, pyrrolidine 2- \& 5-methylene protons), $3.78 \sim 3.89$ (1H, m, SCH), $4.00 \sim 4.06$ (2H, m, H-5 \& H-8). IR (KBr) $3400,1760,1675,1590 \mathrm{~cm}^{-1}$. An analytical sample was obtained as follows. The amorphous powder was dissolved in $\mathrm{MeOH}$, seeded with crystals of previously obtained authentic sample and allowed to stand in a freezer to give colorless fine prisms, $\mathrm{mp} 198 \sim 200^{\circ} \mathrm{C}$ (dec.), which were dried at $40^{\circ} \mathrm{C}$ in vacuo for 46 hours. UV $\lambda_{\max }^{\mathrm{H}_{2} \mathrm{O}} \mathrm{nm}(\varepsilon) 298(10,400)$.

Anal. Calcd. for $\mathrm{C}_{15} \mathrm{H}_{21} \mathrm{~N}_{3} \mathrm{O}_{4} \mathrm{~S} \cdot \frac{1}{2} \mathrm{H}_{2} \mathrm{O}$ : C 51.70, $\mathrm{H}$ 6.36, N 12.06, S 9.20.

Found:

C $51.83, \mathrm{H} 6.67, \mathrm{~N} 11.77, \mathrm{~S} 9.40$.

Acknowledgment

We wish to express our deep gratitude to Dr. K. Murayama, Director of Research Institute and to Dr. H. NAKAO, Director of Chemical Research Laboratories for their valuable advice and encouragement throughout this work. We would also like to thank Mr. H. Misawa, Mr. I. Igarashi, Mr. Y. Utsur and Ms. M. Oyama for carrying out the microbiological assays. 


\section{References}

1) Kahan, J. S.; F. M. Kahan, R. Goegelman, S. A. Currie, M. Jackson, E. O. Stapley, T. W. Miller, A. K. Miller, D. Hendlin, S. Mochales, S. Hernandez, H. B. Woodruff \& J. Birnbaum: Thienamycin, a new $\beta$-lactam antibiotic. I. Discovery, taxonomy, isolation and physical properties. J. Antibiotics 32 : $1 \sim 12,1979$

2) Albers-Schönberg, G.; B. H. Arison, O. D. Hensens, J. Hirshfield, K. Hoogsteen, E. A. Kaczka, R. E. Rhodes, J. S. Kahan, F. M. Kahan, R. W. Ratcliffe, E. Walton, L. J. Ruswinkle, R. B. Morin \& B. G. Christensen: Structure and absolute configuration of thienamycin. J. Am. Chem. Soc. 100: 6491 6499, 1978

3) Tally, F. P.; N. V. Jacobus \& S. L. Gorbach: In vitro activity of thienamycin. Antimicrob. Agents Chemother. 14: 436 438, 1978

4) Kropp, H.; J. S. Kahan, F. M. Kahan, J. Sundelof, G. Darland \& J. Birnbaum: Thienamycin. A new $\beta$-lactam antibiotic. II. In vitro and in vivo evaluation. 16th Intersci. Conf. Antimicrob. Agents Chemother., Abstract No. 228, Chicago, 1976

5) Leanza, W. J.; K. J. Wildonger, T. W. Miller \& B. G. Christensen: $N$-Acetimidoyl- and $N$-formimidoylthienamycin derivatives: Antipseudomonal $\beta$-lactam antibiotics. J. Med. Chem. 22: 1435 1436, 1979

6) Wise, R.; J. M. Andrews \& N. PAtel: N-Formimidoyl-thienamycin a novel $\beta$-lactam: An in-vitro comparison with other $\beta$-lactam antibiotics. J. Antimicrob. Chemother. 7: $521 \sim 529,1981$

7) Kropp, H.; J. G. Sundelof, J. S. Kahan, F. M. Kahan \& J. Birnbaum: MK0787 ( $N$-Formimidoylthienamycin): Evaluation of in vitro and in vivo activities. Antimicrob. Agents Chemother. 17: 993 1000, 1980

8) Ganguly, A. K.; V. M. Girijayallabhan, S. McCombie, P. Pinto, R. Rizvi, P. D. Jeffrey \& S. Lin: Synthesis of Sch 29482 - a novel penem antibiotic. J. Antimicrob. Chemother. 9 Suppl. C: 1 6, 1982, and other papers therein.

9) Tanaka, T.; T. Hashimoto, K. Inno, Y. Sugimura \& T. Miyadera: Penems. I. Novel synthesis of antibacterial penem compounds utilizing 1,3-dithiolane derivatives. Tetrahedron Lett. 23: 1075 1079, 1982

10) Tanaka, T.; T. Hashimoto, K. Inno, Y. Sugimura \& T. Miyadera: Thioxopenams, useful intermediates for penem synthesis. J. Chem. Soc., Chem. Commun. 1982: 713 714, 1982

11) Tanaka, T.; T. Hashimoto, K. Iino, T. Shibata, Y. Sugimura, T. Miyadera \& S. Sugawara: Synthesis and in vitro antibacterial activity of penem derivatives. 4th Symposium on Medicinal Chemistry. Abstract No. 1, Tokyo, 1982

12) Mtyadera, T.: Penems. Symposium on chemistry and structure-activity relationships of the new $\beta$-lactams. 22nd Intersci. Conf. Antimicrob. Agents Chemother., Session 35, Miami Beach, 1982

13) Sugawara, S.; T. Mryadera, Y. Sugimura, S. Goto \& S. Kuwahara: RS-533, a new carbapenem compound. In vitro and in vivo antibacterial activities. 22nd Intersci. Conf. Antimicrob. Agents Chemother., Abstract No. 214, Miami Beach, 1982

14) Ratcliffe, R. W.; T. N. Salzmann \& B. G. Christensen: A novel synthesis of the carbapen-2-em ring system. Tetrahedron Lett. 21: 31 34, 1980. OIDA and coworkers have also reported the synthesis of 2oxocarbapenams by the same method. (S. OIdA, A. Yoshida \& E. OHKI: Synthetic approach directed at 1carbapenems and 1-carbapenams. Chem. Pharm. Bull. 28: 3494 3500, 1980).

15) Kametani, T.; K. Fukumoto \& M. Ihara: Synthesis of carbapenem antibiotics. Heterocycles 17: 463 506, 1982; references cited therein

16) Karady, S.; J. S. Amato, R. A. Reamer \& L. M. Weinstock: Stereospecific conversion of penicillin to thienamycin. J. Am. Chem. Soc. 103: 6765 6767, 1981

17) Shibasaki, M.; A. Nishida \& S. Ikegami: A mild method for the conversion of propiolic esters to $\beta$ keto esters. Application to the formal total synthesis of $( \pm)$-thienamycin. Tetrahedron Lett. 23: 2875 2878,1982

18) Aratani, M.; K. Sawada \& M. Hashimoto: Stereo- and regiospecific allylation of 4-chloroazetidinones with allylsilanes: convergent synthesis of a key intermediate for $(+)$-thienamycin. Tetrahedron Lett. 23: $3921 \sim 3924,1982$

19) Yoshimoto, M.; N. Ishida \& T. Hiraoka: A new general method for carbon-carbon condensation of conjugated enaminoketones at the $\gamma$-position. Tetrahedron Lett. 1973: 39 42, 1973

20) Suyama, T. \& S. Kanao: Decarboxylierung der Aminosäuren. IV. Yakugaku Zasshi 85: 531 533, 1965 